\title{
Evaluation of scute thickness to infer life history records in the carapace of green and loggerhead turtles
}

\author{
Melania C. López-Castro*, Karen A. Bjorndal, Alan B. Bolten \\ Archie Carr Center for Sea Turtle Research and Department of Biology, University of Florida, PO Box 118525, Gainesville,
} FL 32611, USA

\begin{abstract}
Use of scute in biochemical studies to infer ontogenetic changes of habitat and diet in sea turtles is becoming more frequent because scute is an inert tissue with continuous growth that can record habitat and diet changes through time. Changes are detectable through biochemical markers such as stable isotopes and trace elements. These studies are critical for the management of endangered sea turtles because location and foraging requirements of these animals must be known in order to be able to provide effective protection measures. However, scute thickness is not homogeneous throughout the carapace. Depending on where in the scute a sample is collected, a different version of the history of an individual turtle could be obtained. Our goal was to determine where on the carapace the thickest scute is found in green turtles Chelonia mydas and loggerhead turtles Caretta caretta and whether this area reveals the longest life history of the turtle based on stable isotopes of carbon and nitrogen. Our results show that regardless of size, the thickest part of the scute is found in the central region of the second lateral scute in green turtles and of the third lateral scute in loggerheads. Furthermore, the thickest areas do provide the longest records of the history of green turtles and, perhaps, of loggerhead turtles. We were able to observe a clear shift of habitat from the stable isotope values in the central region of the scute of several green turtles that was not observed in the posterior margin. Thus, the central region site should be used to collect scute tissue as this provides information on the life history of sea turtles over the longest period of time.
\end{abstract}

KEY WORDS: Scute thickness $\cdot$ Sea turtles $\cdot$ Biological markers

Resale or republication not permitted without written consent of the publisher

\section{INTRODUCTION}

Understanding the different stages in the life cycle of endangered species allows us to design better measures for their conservation, especially when these species have cryptic life cycles, as do sea turtles. The early stage of most sea turtles, known as the 'lost years', is spent in oceanic waters of unknown location (Carr 1986, Bolten 2003a,b). Finding the locations of oceanic-stage sea turtles has been the focus of several research studies, because we cannot protect turtles if we do not know where they are (Reich et al. 2007, López-Castro et al. 2013, Putman \& Naro-Maciel 2013).
Scute, the keratinous tissue that covers the carapace of turtles, is now commonly used in studies of foraging ecology and habitat use that involve different life stages of sea turtles, including their oceanic stage (Reich et al. 2007, Cardona et al. 2009, 2010, Gorga 2010, Vander Zanden et al. 2010, Howell 2012, López-Castro et al. 2013). Scute is an inert tissue with continuous growth where new tissue is formed underneath older tissue. A core of scute thus records the diet and habitat history of the turtle (Alibardi 2005). These changes can be interpreted with stable isotopes of different elements (e.g. carbon, nitrogen, oxygen, lead), as well as trace elements and other biomarkers (Reich et al. 2007, Hob- 
son 2008, López-Castro et al. 2013). Scute layers can represent a long-term habitat and diet chronology that can be sampled from live turtles more easily than bone tissue can be.

One caveat in using scute is that, although the rate of deposition of new tissue has been estimated (Vander Zanden et al. 2010, 2012), the rate of scute deposition has not been determined empirically and is not known for all size classes of all sea turtle species. Another caveat is that, similar to terrestrial and freshwater turtles, older scute layers on sea turtles slough away at an undetermined rate. This loss limits the temporal scope of the chronology, and probably varies among individuals. Since the work of Reich et al. (2007), scute samples have been collected with $6 \mathrm{~mm}$ biopsy punches from the posterior margin of the second lateral scute in green turtles Chelonia mydas and from the third lateral scute in loggerheads Caretta caretta. Based on the growth pattern of scute (Alibardi 2005), it was believed this area would retain the oldest scute tissue.

Our study determined the best site to sample scute to reveal the longest history of individual turtles. First, we measured scute thickness throughout the carapace of green and loggerhead turtles. Second, we assessed whether the thickest part of the scute retained the longest history, or whether differential thickness resulted from differential scute deposition rates in different regions of the scute.

\section{MATERIALS AND METHODS}

We obtained carcasses of freshly dead turtles from the coasts of Florida, USA (23 green turtles and 1 loggerhead), and the Azores (2 green turtles and 3 loggerheads). We measured minimum curved carapace length (CCL) with flexible fiberglass tape measures to $0.1 \mathrm{~cm}$. The size range was 25.0 to $76.7 \mathrm{~cm}$ for green turtles and 16.3 to $65.2 \mathrm{~cm}$ for loggerhead turtles (Table 1).

We removed all central and lateral scutes from each turtle for a total of 13 scutes for each green turtle and 15 scutes for each loggerhead. After carefully removing all dermal tissue from the scutes with scalpels, we used an electronic digital micrometer (Starrett) with a resolution of $0.001 \mathrm{~mm}$ and an accuracy of $\pm 0.003 \mathrm{~mm}$ to measure thickness along transects for all central and lateral scutes (Fig. 1A) and so to determine the thickest region in the carapace. The number of sites along transects varied depending on the length of the transect. We started measuring at the posterior edge of the scute and then every $1.2 \mathrm{~cm}$
Table 1. Chelonia mydas and Caretta caretta. Curved carapace length (CCL) of individuals and thickness of 2 different regions of the lateral scute for green turtles (second lateral) and loggerhead turtles (third lateral). PM: posterior margin; CR: central region

\begin{tabular}{|c|c|c|c|}
\hline \multirow[t]{2}{*}{ ID no. } & \multirow[t]{2}{*}{$\mathrm{CCL}(\mathrm{cm})$} & \multicolumn{2}{|c|}{ Scute thickness (mm) } \\
\hline & & PM & $\mathrm{CR}$ \\
\hline \multicolumn{4}{|c|}{ Green turtles } \\
\hline 1 & 25.0 & 0.223 & 0.499 \\
\hline 2 & 25.4 & 0.155 & 0.255 \\
\hline 3 & 25.6 & 0.297 & 0.421 \\
\hline 4 & 26.2 & 0.295 & 0.567 \\
\hline 5 & 30.5 & 0.216 & 0.486 \\
\hline 6 & 31.8 & 0.200 & 0.551 \\
\hline 7 & 32.0 & 0.408 & 0.597 \\
\hline 8 & 32.0 & 0.316 & 0.575 \\
\hline 9 & 32.3 & 0.293 & 0.867 \\
\hline 10 & 32.5 & 0.255 & 0.551 \\
\hline 11 & 33.1 & 0.340 & 0.570 \\
\hline 12 & 33.4 & 0.302 & 0.644 \\
\hline 13 & 34.5 & 0.186 & 0.546 \\
\hline 14 & 34.9 & 0.216 & 0.562 \\
\hline 15 & 37.0 & 0.167 & 0.213 \\
\hline 16 & 38.4 & 0.194 & 0.537 \\
\hline 17 & 42.9 & 0.173 & 0.475 \\
\hline 18 & 45.8 & 0.205 & 0.643 \\
\hline 19 & 51.1 & 0.264 & 0.954 \\
\hline 20 & 53.5 & 0.203 & 0.330 \\
\hline 21 & 54.9 & 0.297 & 0.697 \\
\hline 22 & 57.8 & 0.305 & 0.955 \\
\hline 23 & 60.3 & 0.244 & 0.450 \\
\hline 24 & 62.4 & 0.216 & 1.271 \\
\hline 25 & 76.7 & 0.577 & 1.140 \\
\hline \multicolumn{4}{|c|}{ Loggerheads } \\
\hline 26 & 16.3 & 0.342 & 0.313 \\
\hline 27 & 20.7 & 0.414 & 0.441 \\
\hline 28 & 26.2 & 0.157 & 0.195 \\
\hline 29 & 65.2 & 0.860 & 1.637 \\
\hline
\end{tabular}

(distance from one central measuring point to the next) until we reached the anterior margin.

Once the area of the carapace with the thickest scute was determined, we collected 2 core samples using sterile $6 \mathrm{~mm}$ biopsy punches. One sample was collected in the posterior margin where samples have traditionally been collected, and one in the thickest part of the scute.

Each biopsy sample was glued to a glass slide with the dorsal side (oldest tissue) facing up and then subsampled in $50 \mu \mathrm{m}$ layers using a carbide end mill. Scute is subsampled in $50 \mu \mathrm{m}$ layers because this depth provides the minimum amount required for stable isotope analysis. Each layer was analyzed for stable isotopes of carbon and nitrogen at the Department of Geological Sciences Light Stable Isotope Lab at the University of Florida, using an ECS 4010 elemental analyzer (Costech) interfaced via a ConFlo III 


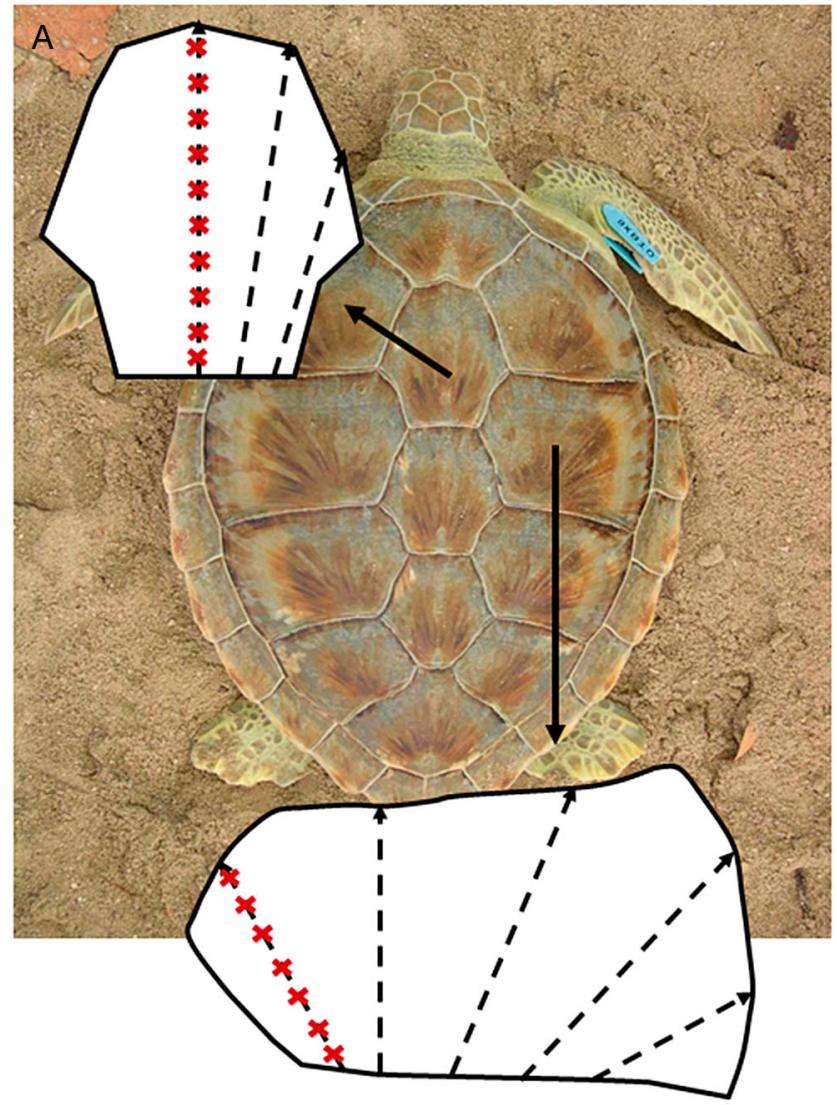

to a DeltaPlus XL isotope ratio mass spectrometer (ThermoFisher Scientific). Stable isotope abundances (ratio of heavy to light isotopes) were expressed in delta notation ( $\delta \mathrm{X}$ in the equation below, where $\mathrm{X}$ is either $\mathrm{C}$ or $\mathrm{N})$, in parts per thousand (\%):

$$
\delta \mathrm{X}=\left(R_{\text {sample }} / R_{\text {standard }}-1\right) \times 1000
$$

where $R_{\text {sample }}$ and $R_{\text {standard }}$ are the ratios of heavy to light isotopes $\left({ }^{13} \mathrm{C} /{ }^{12} \mathrm{C}\right.$ and $\left.{ }^{15} \mathrm{~N} /{ }^{14} \mathrm{~N}\right)$ in the sample and international standard, respectively. The standards used were Vienna Pee Dee Belemnite for ${ }^{13} \mathrm{C}$ and atmospheric $\mathrm{N}_{2}$ for ${ }^{15} \mathrm{~N}$. L-glutamic acid (reference material USGS40) was used to normalize all results. The standard deviation of the reference material was $0.09 \%$ for $\delta^{13} \mathrm{C}(\mathrm{n}=136)$ and $0.10 \%$ o for $\delta^{15} \mathrm{~N}$ values ( $\mathrm{n}=146)$. Repeated measures of loggerhead scute were used to examine consistency in a homogeneous reference material of similar isotopic composition. Standard deviation of the loggerhead scute was $0.08 \%$ o for $\delta^{13} \mathrm{C}$ and $0.13 \%$ for $\delta^{15} \mathrm{~N}$ values $(\mathrm{n}=59)$.

We compared the number of layers and the stable isotope values obtained from the 2 samples (posterior margin and the central region of the scute) to determine whether the central part of the scute contains a longer history record than the posterior margin. To

\section{B}

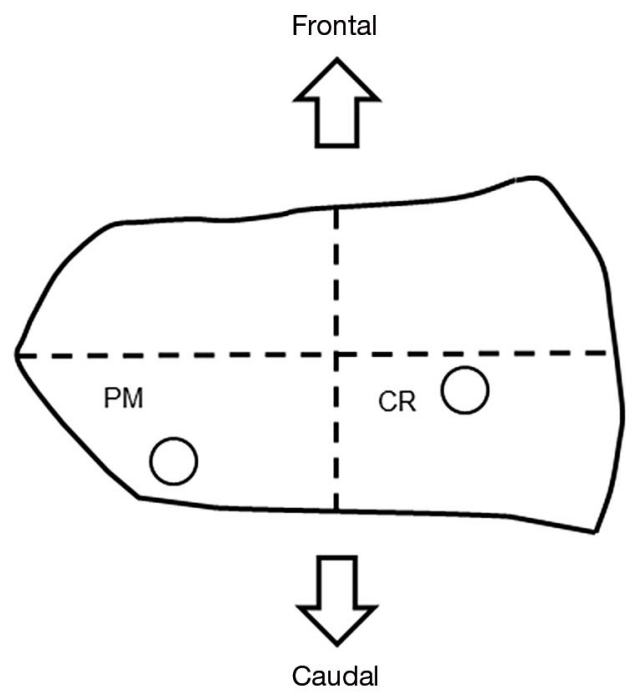

Fig. 1. Chelonia mydas. (A) Location of the central and lateral scutes on the carapace of a green turtle, and the pattern of transects used to measure the thickness of each central and lateral scute. Measurement points were $1.2 \mathrm{~cm}$ apart over the transect lines (represented by red crosses on one line). (B) Sample locations in the second lateral scute. CR: central region (thickest part of the scute); PM: posterior margin (traditional sample site)

determine if there was a correlation between the central region and posterior margin of the scute (i.e. if values between sampling regions were similar), we compared $\delta^{13} \mathrm{C}$ values using a Wilcoxon signed rank test in $\mathrm{R}$ for each of the species. We performed a 2 -tailed paired $t$-test using the package lawstat in $\mathrm{R}$ to compare the thickness of the posterior margin and the central region for each species. We also ran a Pearson's product-moment correlation test using the package MASS in R to test if there was a positive correlation between the thickness of the scute (posterior margin or central region) and the CCL of the turtle for both species.

\section{RESULTS}

Scute thickness varied over the surface of the carapace. The thickest scute was in the central region, in the lower distal quadrant (Fig. 1B) of the second lateral scute in green turtles and of the third lateral scute in loggerheads. Because our goal was to compare the thickest area of the scute with that of the traditional sample site, measurements of other scutes are not reported here. Thicknesses of scutes in the 


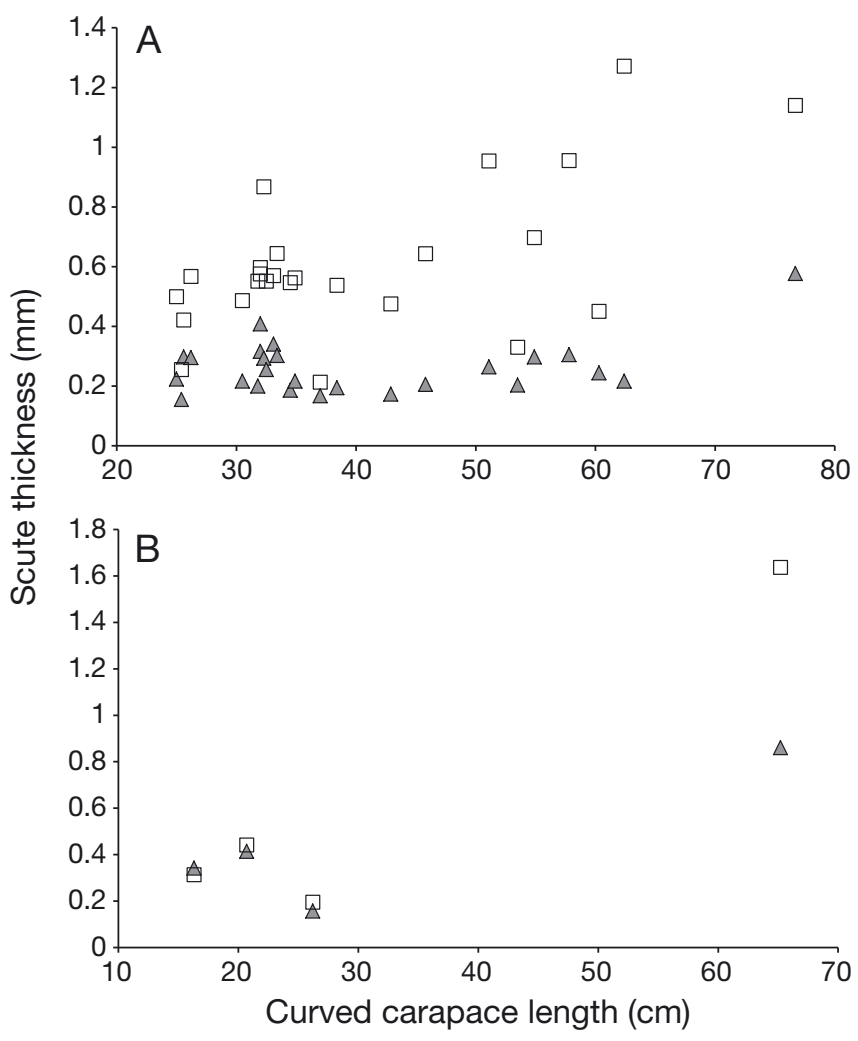

Fig. 2. Chelonia mydas and Caretta caretta. Thickness of central region $(\square)$ and posterior margin $(\triangle)$ of the scute in relation to curved carapace length in (A) green turtles and

(B) loggerhead turtles. Note the different $x$ - and $y$-axes

central and posterior regions (Table 1) were significantly different in green turtles $(t=-8.0326$, df $=24$, $\mathrm{p}<0.0001$ ). In loggerheads, there was a nonsignificant trend for greater thickness in the central region $(t=-1.0661, \mathrm{df}=3, \mathrm{p}<0.3646)$. A larger sample size is needed for a more robust comparison.
As expected, larger turtles had thicker scutes than smaller turtles. We found a positive correlation between CCL and the thickness of both the posterior margin (Pearson's $r=0.353, \mathrm{n}=25, \mathrm{p}=0.041$ ) and the central region (Pearson's $r=0.610, n=25, p=0.0006$ ) for green turtles (Fig. 2A). In loggerheads, we found no correlation between CCL and thickness of the posterior margin (Pearson's $r=0.872, n=4, p=0.063$ ) but a positive correlation between CCL and thickness of the central region (Pearson's $r=0.959, \mathrm{n}=4$, $\mathrm{p}=0.020)$. Results for loggerhead turtles should be interpreted with caution due to the small sample size (Fig. 2B).

Patterns in each of the 2 scute regions analyzed were similar for carbon and nitrogen stable isotopes. Therefore, only the carbon values are shown (Figs. 3 \& 4).

The starting point of our subsampling may have been slightly offset due to uneven wear of the scute. When comparing the layers obtained from each region of the scute, stable isotope values of carbon were similar between the 2 sites for both green turtles (Wilcoxon's $V=2021.5, \mathrm{p}=0.4273$; Fig. 3A) and loggerhead turtles (Wilcoxon's $V=127, \mathrm{p}=0.05163$; Fig. 3B). Based on the isotopic values used by Reich et al. (2007) to differentiate between neritic and oceanic tissues in the scute samples, we observed 2 groups of green turtles, one in which turtles had $\delta^{13} \mathrm{C}$ values between -8 and $-13 \%$ o (neritic stage) and one with $\delta^{13} \mathrm{C}$ values between -17 and $-20 \%$ (oceanicstage turtles; Fig. 4A,B). The central region and posterior margin of the scute had similar signatures in all layers that were present in both samples starting at the ventral surface of the scute (Fig. 4A,B). However, there were substantial changes in the isotope values of $\delta^{13} \mathrm{C}$ that were only observed in the central region
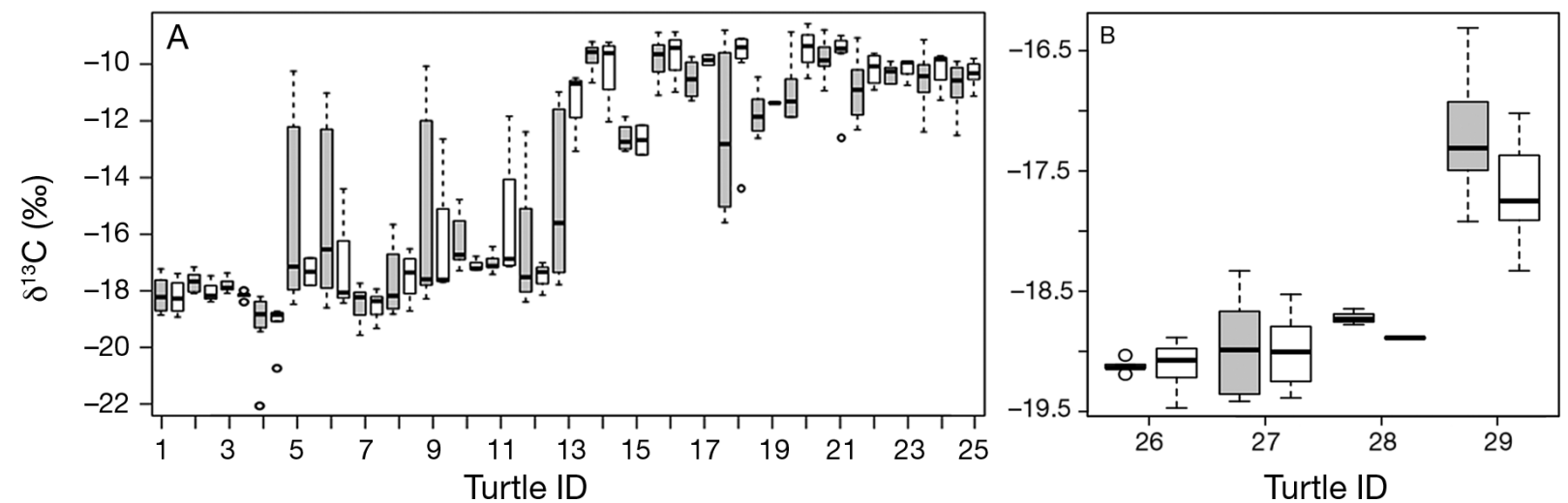

Fig. 3. Chelonia mydas and Caretta caretta. Comparison of the distribution of isotope values of carbon from the central region (gray) and the posterior margin of the scute (white) in (A) green turtles and (B) loggerhead turtles. ID numbers refer to Table 1. The box is the interquartile range (second and third quartiles), the horizontal line within the box is the median, whiskers represent lower and upper fences of the first and fourth quartiles, and outliers are represented by the circles 


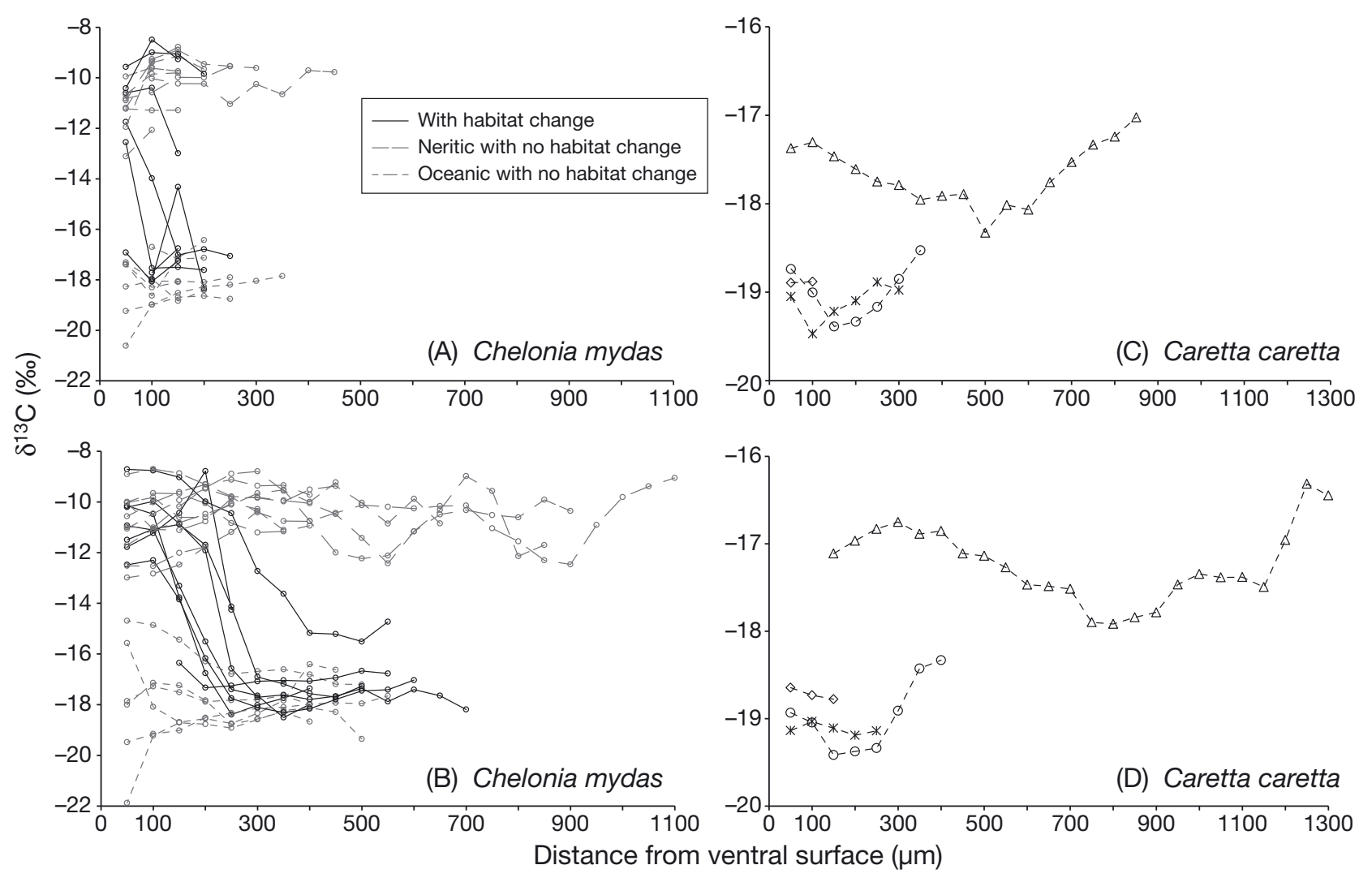

Fig. 4. Chelonia mydas and Caretta caretta. Isotope values of carbon in 2 different regions of the scute of $(\mathrm{A}, \mathrm{B})$ green turtles and $(C, D)$ loggerheads. Panels $A$ and $C$ refer to the posterior margin of the scute; panels B and D refer to the central region of the scute. In panels A and B, green turtles are divided into 3 groups based on habitat use, indicated by line types. In panels $C$ and $\mathrm{D}$, the individual loggerheads are identified by different symbols. Values for corresponding layers between the central region and the posterior margin are not always identical because the $50 \mu \mathrm{m}$ layers have slightly different starting points due to uneven wear of the scute. The $x$-axis extends from youngest to oldest tissue

(Fig. 4B) and not in the posterior margin (Fig. 4A) of the scute. At the beginning of the time series (further from the ventral surface), critical information on shifts from oceanic to neritic habitats was present in the thicker, central samples but had been lost from the posterior layers in several of the green turtles. Therefore, the central region was not only thicker, but also contained a longer history than the posterior sampling site, as evidenced by several green turtles that showed a habitat change in the central region of the scute but not in the posterior margin.

In loggerhead turtles, there was only 1 group with isotope values between -16 and $-20 \% \delta^{13} \mathrm{C}$ (Fig. $4 \mathrm{C}, \mathrm{D}$ ). No substantial change was observed between the posterior margin and the central region, except for the turtle with the most layers in which an increase in $\delta^{13} \mathrm{C}$ was observed in the oldest layers (1150 to $1300 \mu \mathrm{m}$ from the ventral surface; Fig. 4D). For this turtle, we believe we did not collect a full-depth core in the posterior margin sample and lost the youngest layers.

\section{DISCUSSION}

We found that the central region holds a longer record of the history of green turtles and, perhaps, of loggerhead turtles than does the posterior margin of the scute. This longer history observed in green turtles indicates that the greater thickness in the central area of the scute is a result of longer retention of the scute, not a more rapid deposition rate of scute compared with the posterior margin. A more rapid deposition rate would have yielded more layers with the same isotope values in the central region. Apparently, surface scute tissue is sloughed more rapidly in the posterior margin area.

The difference between sampling sites could affect our interpretation of the history of the turtles, depending on the size of the turtle. In small turtles, i.e. those $<15 \mathrm{~cm} \mathrm{CCL}$, the difference in thickness between the posterior margin and central region of the scute might be minimal, and the isotope values of each layer should be similar. However, in larger tur- 
tles, $>25 \mathrm{~cm} \mathrm{CCL}$, a sample collected in the posterior margin will yield a shorter record of the life of the turtle, limiting conclusions. Although it is usually not possible to obtain the complete history of a turtle from the scute, more of the tissue layers are preserved in the central region and thus allow us to decipher more of the turtle's history compared to the posterior margin.

Detailed studies of scute growth and loss in different species and size classes are needed because of the increased use of scute in studies of sea turtle natural history with direct implications for conservation. More studies are also needed on the rate of scute deposition, so that we can become more confident in estimates of the length of time reflected in a $50 \mu \mathrm{m}$ sample. Current estimates rely on rates of isotopic incorporation and turnover rates (Vander Zanden et al. 2010, 2013). Moreover, almost all turtles in this study came from Florida, and it is possible that turtles elsewhere may show a different pattern of scute growth caused by factors such as the availability and type of resources, and temperature (Limpus \& Chaloupka 1997, Bjorndal et al. 2003, Roark et al. 2009). Turtles from other regions in the Atlantic and other parts of the world should be studied to confirm whether the pattern we observed in the scute of green turtles in the North Atlantic applies to other regions.

Acknowledgements. This research was funded by a Boyd Lyon Sea Turtle Fund Scholarship, the Florida Sea Turtle License Plate Grants Program, the PADI Foundation, the Explorers Club Exploration Fund, the National Fish and Wildlife Foundation, and Sigma Xi. All samples were collected under appropriate national research permits, imported under CITES permits (09US724540/9 and 10US724540/9), and collected and processed in compliance with the Institutional Animal Care and Use Committee at the University of Florida. We thank M. Pajuelo, J. Pfaller, M. Santos, and $\mathrm{H}$. Vander Zanden for assistance with the collection of samples, and J. Curtis for his help with the stable isotope analysis.

\section{LITERATURE CITED}

Alibardi L (2005) Proliferation in the epidermis of chelonians and growth of the horny scutes. J Morphol 265:52-69

$>$ Bjorndal KA, Bolten AB, Dellinger T, Delgado C, Martins HR (2003) Compensatory growth in oceanic loggerhead sea turtles: response to a stochastic environment. Ecology 84: 1237-1249

Editorial responsibility: Jeffrey Seminoff,

La Jolla, California, USA
Bolten AB (2003a) Active swimmers - passive drifters: the oceanic juvenile stage of loggerheads in the Atlantic system. In: Bolten AB, Witherington BE (eds) Loggerhead sea turtles. Smithsonian Institution Press, Washington, DC, p 63-78

Bolten AB (2003b) Variation in sea turtle life patterns: neritic vs. oceanic developmental stages. In: Lutz PL, Musick JA, Wyneken J (eds) The biology of sea turtles, Vol 2. CRC Press, Boca Raton, FL, p 243-257

> Cardona L, Aguilar A, Pazos L (2009) Delayed ontogenetic dietary shift and high levels of omnivory in green turtles (Chelonia mydas) from the NW coast of Africa. Mar Biol 156:1487-1495

> Cardona L, Campos P, Levy Y, Demetropoulos A, Margaritoulis D (2010) Asynchrony between dietary and nutritional shifts during the ontogeny of green turtles (Chelonia mydas) in the Mediterranean. J Exp Mar Biol Ecol 393:83-99

Carr A (1986) Rips, FADS, and little loggerheads. Bioscience 36:92-100

Gorga CT (2010) Foraging ecology of green turtles (Chelonia mydas) on the Texas coast, as determined by stable isotope analysis. MS thesis, Texas A\&M University, College Station, TX

> Hobson KA (2008) Using endogenous and exogenous markers in bird conservation. Bird Conserv Int 18:S174-S199

Howell LN (2012) Ontogenetic shifts in diet and habitat by juvenile green sea turtles (Chelonia mydas) along the middle and lower Texas coast. MS thesis, Texas A\&M University, Galveston, TX

Limpus C, Chaloupka M (1997) Nonparametric regression modelling of green sea turtle rates (southern Great Barrier Reef). Mar Ecol Prog Ser 149:23-34

López-Castro MC, Bjorndal KA, Kamenov GD, ZenilFerguson R, Bolten AB (2013) Sea turtle population structure and connections between oceanic and neritic foraging areas in the Atlantic revealed through trace elements. Mar Ecol Prog Ser 490:233-246

Putman NF, Naro-Maciel E (2013) Finding the 'lost years' in green turtles: insights from ocean circulation models and genetic analysis. Proc Biol Sci 280:20131468

Reich KJ, Bjorndal KA, Bolten AB (2007) The 'lost years' of green turtles: using stable isotopes to study cryptic lifestages. Biol Lett 3:712-714

> Roark AM, Bjorndal KA, Bolten AB (2009) Compensatory responses to food restriction in juvenile green turtles (Chelonia mydas). Ecology 90:2524-2534

> Vander Zanden HB, Bjorndal KA, Reich KJ, Bolten AB (2010) Individual specialists in a generalist population: results from a long-term stable isotope series. Biol Lett 6 : 711-714

- Vander Zanden HB, Bjorndal KA, Mustin W, Ponciano JM, Bolten AB (2012) Inherent variation in stable isotope values and discrimination factors in two life stages of green turtles. Physiol Biochem Zool 85:431-441

> Vander Zanden HB, Bjorndal KA, Bolten AB (2013) Temporal consistency and individual specialization in resource use by green turtles in successive life stages. Oecologia $173: 767-777$

Submitted: November 20, 2013; Accepted: February 24, 2014 Proofs received from author(s): May 9, 2014 